\title{
Breastfeeding Practices: A Cross-Believed Perspective
}

\author{
Hanifah Musa Fathullah Harun \\ Academy of Contemporary Islamic Studies (ACIS), \\ Universiti Teknologi MARA, 40450, Shah Alam, Malaysia. \\ Siti Noorbiah Md. Rejab \\ Academy of Contemporary Islamic Studies (ACIS) \\ Universiti Teknologi MARA, 40450, Shah Alam, Malaysia. \\ Zakiah Samori \\ Senior Lecturer, Academy of Contemporary Islamic Studies \\ Universiti Teknologi MARA, 40450, Shah Alam, Selangor,Malaysia.
}

\begin{abstract}
Breastfeeding practices have been so common among Muslim mothers in the community that children are breastfed even after their baby phase. Breastfeeding can contribute to mental and physical growth of children. The significance and benefits of breast milk have not only been recognized in Islam, but also by medical science and nutrition research. This article aims to discuss the infant feeding practices based on religious and scientific foundation in the Muslim community, with a primary focus on the advantages of breastfeeding as well as syariah-related issues on breastfeeding. The research methodology used in this paper is the analysis of books and papers related to breastfeeding. The results of this discussion have confirmed the benefits of breastfeeding from the Islamic and scientific perspectives.
\end{abstract}

Keywords: breastfeeding, fiqh, mother's milk, baby, Islamic perspective, scientific perspective

\section{INTRODUCTION}

According to Abdul Karim Ali (2006), an application of maqasid syari'ah in a marriage is the protection of the family lineage by ensuring sustainable human generation who believe.

Rasulullah (pbuh) in his Hadith has meant:

"A man came to the Prophet and said: "O Messenger of Allah, I have found a woman's descent and a resident except that she cannot bear children, whether I should marry her?" Then he forbade it. Then he came a second time, but he forbade it. Then came the third time, but he still forbade him and said: "Marry women who bear children more loving because I am proud of the large number of you." (Al-Nasa i, No: 3228, Abu Dawood, No: 2050, following the pronouncement of this Hadith narrated by al-Nasa`i).

Islam has placed having a child as one of the goals of marriage. The duties of parents towards their children are to care, protect, educate and the like. Breastfeeding is one of the ways and efforts in caring for the child as well as in strengthening the family system and the bond of love in accordance with the advice of the Qur'an. Breast milk is the source of a balanced diet and it has been proven to ensure health, mental and physical growth of babies leading to being healthier and wholesome. 
Breastfeeding benefits have not only highlighted on the breast milk contents, as that have been stated in the Quran and Hadith, but it has also been proven scientifically. Breast milk contains substances that are highly nutritious for baby's needs to grow as compared to the substances found in milk formula. Multiple substances in breast milk make it as a shield to protect the baby from many diseases (Bond \& Filler, 1981). Malaysian Breastfeeding Policy recommends "All mothers are encouraged to breastfeed their children with breast milk from birth until six months of age and to be continued until the age of two years. Complementary foods should be given from the age of six months." However, in recent years, many mothers tend to give formula to replace breast milk (UNICEF, 2008). Over the years, only two of seven babies in Malaysia are exclusively breastfed for the first four months of life, which is two months shorter than the six months recommended by the World Health Organization (WHO) and the United Nations Children Education Fund (UNICEF). Parents choose not to give their babies the best at the beginning of their lives, and they too choose to replace breast milk, that is the ultimate infant nutrition; with formula substitute which is less powerful as found in milk formula, cow's milk, condensed milk, evaporated milk and beverages such as coffee, tea and sugar water (UNICEF, 2008). According to UNICEF representative in Malaysia, Encik Youssouf Oomar, "Giving food or drink other than breast milk to the baby increases the risk of babies against diarrhea, pneumonia, ear infections, runny nose and other infections caused by bacteria, and breastfeeding reduces these risks". Threats like these on the health and survival of the baby and the baby's development are very significant in developing and non-developing countries. These countries are where babies are exclusively breastfed for the first six months ahead in life and those of the same age given formula substitutes.

Therefore, this article is produced with the main objective that is to discuss infant feeding practices based on the religious and scientific foundation in Muslim community. Its primary focus is on the advantages of breastfeeding to infants in association with syari'ah-based issue on breastfeeding. The research methodology used in this study is a content analysis that focuses on the fiqh of manuscripts and books in the field of medical and related paperwork. This article was written in accordance with the division of the following: the first part discusses the concept of breastfeeding in Islam as well as the call of the Quran and Hadith regarding breastfeeding, and then followed by the discussion on the advantages of breastfeeding from the religious and scientific perspectives, prior to the next section which discusses issues related to the Islamic practices on breastfeeding. This article ends with the closing and proposals for intensifying the practices of breastfeeding to infants in the Muslim community.

\section{The Concept of Breastfeeding in Islam}

Breastfeeding is a natural disposition that has a very large impact, especially in terms of health-related matters on infant. Islam strongly encourages breast-feeding because it is one way and an effort to strengthen the bond of kinship and affection with reference made in the Quran. The definition of breastfeeding can be divided into two, namely the meaning of the term in the language and in accordance with Islamic law. According to the language, the term is derived from the word ar-rada'ah which means breast milk or the arrival of women into the baby's stomach. Women who are breastfeeding are called in Arabic as al-murdi'ah, while the child that is breastfed is called al-radi'. According to the Islamic terminology of the Shafi'i sect, it states that breastfeeding is an act that is to enter the milk of a woman into the child's meals which affects growth (al-Sharbini, xxxx). UNICEF defines breastfeeding as that baby receiving only breast milk (including breast milk that has been removed or breast milk from a wet 
nurse) without other resources, except for Oral Rehydration Solutions (ORS), medicines, vitamins and minerals to the baby.

Based on the meaning and definition discussed, it can be concluded that the meaning of breastfeeding is to put into the cavity of a child who is not more than two years old called the ar-rada'ah. This has been stated 14 times in seven chapters, and from eight verses in the Quran.

Table 1: Ayat on Breastfeeding in the Quran

\begin{tabular}{|c|c|c|}
\hline Name of the Surah & & The Meaning of the Ayat in the Quran \\
\hline al-Baqarah: & 233 & $\begin{array}{l}\text { "Mothers may breastfeed their children two complete years for whoever wishes to } \\
\text { complete the nursing [period]. Upon the father is the mothers' provision and their } \\
\text { clothing according to what is acceptable. No person is charged with more than his } \\
\text { capacity. No mother should be harmed through her child, and no father through his } \\
\text { child. And upon the [father's] heir is [a duty] like that [of the father]. And if they both } \\
\text { desire weaning through mutual consent from both of them and consultation, there is no } \\
\text { blame upon either of them. And if you wish to have your children nursed by a substitute, } \\
\text { there is no blame upon you as long as you give payment according to what is acceptable. } \\
\text { And fear Allah and know that Allah is Seeing of what you do." }\end{array}$ \\
\hline at-Talaq: & 6 & $\begin{array}{l}\text { "...Lodge them [in a section] of where you dwell out of your means and do not harm } \\
\text { them in order to oppress them. And if they should be pregnant, then spend on them until } \\
\text { they give birth. And if they breastfeed for you, then give them their payment and confer } \\
\text { among yourselves in the acceptable way; but if you are in discord, then there may } \\
\text { breastfeed for the father another woman." }\end{array}$ \\
\hline an-Nisa': & 23 & $\begin{array}{l}\text { "Prohibited to you [for marriage] are your mothers, your daughters, your sisters, your } \\
\text { father's sisters, your mother's sisters, your brother's daughters, your sister's daughters, } \\
\text { your [milk] mothers who nursed you, your sisters through nursing, your wives' mothers, } \\
\text { and your step-daughters under your guardianship [born] of your wives unto whom you } \\
\text { have gone in. But if you have not gone in unto them, there is no sin upon you. And [also } \\
\text { prohibited are] the wives of your sons who are from your [own] loins, and that you take } \\
\text { [in marriage] two sisters simultaneously, except for what has already occurred. Indeed, } \\
\text { Allah is ever Forgiving and Merciful." }\end{array}$ \\
\hline al-Qasas: & 7 & $\begin{array}{l}\text { "And We inspired to the mother of Moses, "Suckle him; but when you fear for him, cast } \\
\text { him into the river and do not fear and do not grieve. Indeed, We will return him to you } \\
\text { and will make him [one] of the messengers." }\end{array}$ \\
\hline
\end{tabular}




\begin{tabular}{|c|c|c|c|}
\hline al-Qasas: & & 12 & $\begin{array}{l}\text { "And We had prevented from him [all] wet nurses before, so she said, "Shall I direct you } \\
\text { to a household that will be responsible for him for you while they are to him [for his } \\
\text { upbringing] sincere?" }\end{array}$ \\
\hline al-Hajj & ayat & 2 & $\begin{array}{l}\text { "On the Day you see it every nursing mother will be distracted from that [child] she was } \\
\text { nursing, and every pregnant woman will abort her pregnancy, and you will see the } \\
\text { people [appearing] intoxicated while they are not intoxicated; but the punishment of } \\
\text { Allah is severe." }\end{array}$ \\
\hline al-Ahqaf: & & 15 & $\begin{array}{l}\text { "And We have enjoined upon man, to his parents, good treatment. His mother carried } \\
\text { him with hardship and gave birth to him with hardship, and his gestation and weaning } \\
\text { [period] is thirty months. [He grows] until, when he reaches maturity and reaches [the } \\
\text { age of] forty years, he says, "My Lord, enable me to be grateful for Your favor which } \\
\text { You have bestowed upon me and upon my parents and to work righteousness of which } \\
\text { You will approve and make righteous for me my offspring. Indeed, I have repented to } \\
\text { You, and indeed, I am of the Muslims." }\end{array}$ \\
\hline Luqman: & & 14 & $\begin{array}{l}\text { "And We have enjoined upon man [care] for his parents. His mother carried him, } \\
\text { [increasing her] in weakness upon weakness, and his weaning is in two years. Be } \\
\text { grateful to Me and to your parents; to Me is the [final] destination..." }\end{array}$ \\
\hline
\end{tabular}

Apart from the Quran, there are many traditions of the Prophet (pbuh) which present the advantages of breastfeeding as well as breastfeeding due to illegal conviction. Among these Hadiths, there is one that the Prophet (pbuh) says:

Umm Salamah reported that the Messenger of Allah said: Do not be banned from breastfeeding as breastfeeding strengthens the intestines through the nipple and it happens before the baby is weaned (usually) (al-Tirmidhi, al-rada'ah book, Chapter on Adult Breastfeeding).

Rasulullah (pbuh) said: Verily feeding is due to starving (al-Bukhari, Book of Marriage, chapter on breastfeeding after two years).

The Prophet (pbuh) has a saying that means: There is no law except that breast milk strengthens bones and flesh growth (al-Shawkani, Book on Marriage, Chapter on Adult Breastfeeding).

The Quran and Hadith clearly state that breastfeeding is recommended because it is the best food for the baby and helps the mental and physical growth of a healthy baby.

\section{The Importance of Breastfeeding According to the Quran Fulfilling the Rights of Infants}

Within the family, parents play a major role in maintaining and caring for the family to provide physical and mental needs. Breastfeeding process has very large benefits to the baby and 
mother and this subsequently affects the individual's religion and health. Thus, Islam strongly encourages healthy mothers to breastfeed their babies. It is an effort that must be undertaken in order to enhance the right of a baby to enjoy the advantages and benefits of breast milk. It is most comprehensive for a period of two years for a mother to breastfeed her infant, as outlined in the Quran as found in Surah al-Baqarah, verse 23, that is breastfeeding takes two years starting from the day the baby was born.

Islam also requires that a mother and father to find a wet nurse to meet the baby's needs. In tracing the history of Islam, Prophet Muhammad (pbuh) was suckled by a wet nurse when he was a child. According to scholars of Shafi'i sect, mothers give the first suckle or the milk first puff that is proportional for three to seven days. The physical condition of the milk is that it is thick milk and yellow in colour, and during this period it is known as laba'. Studies have proven that milk that comes out during this period is very important for the child's health as well as its survival and antibodies (Ayu Aima Yusof, 2002).

Nowadays, there are many diseases that not only affect adults, but they also involve babies and children. The problem for infants and toddlers is lack of antibody or resilience in fighting the diseases. According to Danial Zainal Abidin (2007) on 29 July 2005, in conjunction with World Breastfeeding Week, Confederation of American Health Organization emphasized the advantages of breastfeeding when the baby is going through a critical growth process, particularly during the first two years after birth. There are a variety of risks that can happen to a child who does not receive breast milk. Among the risks that have been described are diarrhea, respiratory tract infections, ear infections and mental growth retardation. Thus, these benefits are advantageous, in particular when breastfeeding, as encouraged by the Quran, relates it that the two-year breastfeeding duration is also relevant to scientific discoveries in the field.

Moreover, according to Faruq al-Sheikh Abd Al-Sheikh (2009), breastfeeding also helps a mother's uterus to return to its original position and significantly, breastfeeding may also reduce the incidence of cervical cancer compared to women who did not breastfeed. It is nonexaggeration to say that breastfeeding is one way to preserve the lineage and life and that it meets the requirements of the maqasid syari'ah.

\section{Early Childhood Education}

Breastfeeding is more than just meet the needs of the baby, but it is also an approach in early childhood education. Being the main component bestowed by Allah swt to the mother and child, this act completes the spiritual and physical needs. Physical needs is a requirement to be fulfilled for the baby's immune system through breastfeeding, while the spiritual needs is affection and a feeling of protection afforded by a mother to make the baby feel comfortable and safe. In addition, it is undeniable that breastfeeding is a method that can strengthen the bond between a mother and the child. Breastfeeding has a very great strength as recommended in the words of Allah swt in Surah al-Qasas: 7.

\section{Breastfeeding Allows Mahram Relationship}

Moreover, Islam requires a mother to breastfeed her baby who is not subject to the prior permission of the guardian of the baby. In this situation, the power of the milk, is not only to be a cure for the disease, but it also able to establish a relationship between a wet nurse with the 
baby, and the relationships with wet nurse's children is a ban to marriage. Prophet Muhammad (pbuh) said, which means

"It is illegal because breastfeeding is due to consanguinity."

(Sunan Ibn Majah, al-Nikah Book, Chapter 34, Hadith no. 1937).

Islam forbids the existence of a relationship between two people who have a relationship through breastfeeding. This is because, breastfeeding a baby is a way of getting food that can form flesh and bones, which eventually affect the growth of the baby (Al-Zuhaili, 2007). Among those who become mahram to suckler are: i)women who breastfeed, ii)husband of the wet nurse, iii)parents of a wet nurse, iv)parents of a wet nurse's husband, v)siblings of the wet nurse, vi)siblings to wet nurse's husband, vii)children to parents viii)children to wet nurse and ix)children to father who is wet mother's husband. While those who are mahram to wet nurse and her husband, is her suckling, so also the children of her suckling to the bottom lineage. Parents, grandmother, mother or uncle and siblings to the child is not a mahram to milk parents. This is because milk siblings are not a mahram to the milk father, grandparents and above, such as those siblings of the mother or uncle. Mahram law is only applicable to its furu', such as the milk children's children, grandchildren and the subsequent generation downwards.

\section{Grooming a Personality}

Breast milk is the kind of food that makes up the blood and is able to shape the personality of the child. In one narration mentioned, when Imam Haramain (teacher of Imam al-Ghazali) was a child, he was suckled by a woman who is not known, when his mother was ill. The Imam's father at that time was trying to remove out the milk fearing that it became flesh of the baby and that he would inherit a female character who was not known (Ayu Aima Yusof, 2002). History has also put Prophet Muhammad (pbuh) as a role model in encouraging parents to breastfeed. Prophet Muhammad (pbuh) was introduced with breast milk since he was a child. He was breastfed by two women that was Suwaibah who was a slave to Abu Lahab before he was breastfed by Halimah Al-Saadiah of Bani Saad. Halimah al-Saadiah's personality has a big influence on the life of Prophet Muhammad (pbuh). Therefore, a mother who wants to find a wet nurse for her baby, should find one who has high morals and character.

\section{Breastfeeding from the Scientific Perspective}

In addition to the advantages mentioned in the Quran, the idea put forward by scientists from the observation of the phenomena of nature is in no way contradicting the Quran. Scientific research carried out on mother's milk indicates its overall benefits to the infant, mother, family, community and country in general. It is a well-known fact that breast milk is the liquid produced naturally and psychologically for infants. According to scientists, breast milk is dynamic and alive. It continues to change in terms of nutrient composition to meet the baby's needs in line with the changing age of the baby during lactation. For babies who are born premature, breast milk contains high protein content. Meanwhile, for the eight-month old baby, breast milk contains high calories. In addition, breast milk also changes based on the weather. When the weather is warm, breast milk will increase compared to the cold conditions when it contains more fat. The change also depends on the diet taken by the mother. This is to allow the baby to try a variety of flavours in the weaning period. Among the advantages of breast milk to the baby, according to the scientific perspective includes: 


\section{The Content of Colostrum is High}

Colostrum is the first milk that a mother drips as thick yellowish substance where the protein content is three times more common than breast milk. It includes high level antibodies and white blood cells. It also contains Vitamin A as well as the concentration of chlorine and sodium. Colostrum has an amazing ability to flex the baby's intestines, which in turn pass meconium stool which is the first dark and black excrete. This excrete should pass in the intestine, but remaining in there may cause a blockage of the intestinal tract of the baby. According to scientists, colostrum contains secretory immunoglobulin A or algae, which are anti-infective agent that protects the baby's gut of germ line and the foreign protein in which can cause serious allergies. They have found a new substance in breast milk known as pancreatic secretory trypsin inhibitor (PSTI), which works to protect and improve the baby's intestinal tract. These materials are found in all milk, but its content is seven times higher in the colostrum to provide additional protection for the baby's intestines which are still immature (Farahwahida, 2011). Khulqi Rashid (2007) also discloses in writing that the advantages and benefits of breast milk can be seen from the aspects of immunology and intelligence. These benefits are divided into five areas, namely:

i. Mother's milk contains anti-infective agents, clean and free from contamination.

ii. Levels of immunoglobulin A (Ig.A) in colostrum is high. Secretory Ig.A is not absorbed, but it can paralyze culturing bacteria and other viruses like pathogenic E.coli in the digestive tract.

iii. Breast milk contains lysosim iaituenzim that protects infants from bacteria (E. coli and Salmonella) and viruses. Total lysosium in mother's milk is 300-fold compared to dairy products.

iv. The white blood cells in the mother's milk in the first two weeks are more than 4,000 cells per mile which comprise three types namely:

a. Brochus-Asociated Lympocyte Tissue (BALT) - respiratory antibody

b. Gut-Asociated Lympocyte Tissue (GALT) - respiratory tract antibody

c. Asociated Lympocyte Tissue (MALT) - antibodies in breast tissue

$\mathrm{v}$. There is bifidus factor that is a type of carbohydrate that contains nitrogen which then becomes the pillar of lactobacillus bifidus bacteria growth. These bacteria keep acidity in infant intestinal flora and are useful for inhibiting the growth of bacteria which is not in need.

\section{Prolonged Life}

A study by the United Nations Children's Education Fund (UNICEF) has proven the efficacy of breast milk that it reduces the risk of infant and child mortality. Studies in developing countries show that the percentage increases between 10 to 15 times for those who are not breastfed within three months of birth. Most of the deaths caused by diarrheal diseases are serious. The study also found that as many as 40,000 children die each day, which means 28 people per minute in the developing countries where they are made up of victims of malnutrition. Therefore, scientists have identified seven effective ways to save millions of children's lives, and one of them is to increase the rate of breastfeeding (Farahwahida, 2011).

\section{Increase in the Level of Academic Achievement and IQ}

The content of breast milk also includes fatty acids docosahexaenoic (DHA) and arachidonic acid (AA). Studies conducted by the Retina Foundation of the Southwest in Dallas found that Texas babies get DHA and AA for long-lasting and exclusive excellence of the memory, and are able to solve problems and better able to master the language than those who only received 
DHA or AA only (Danial Zainal Abidin, 2007). Similarly, the opinion expressed by Karen Pryor in her book entitled "Nursing Your Baby" proves that breastfed babies showed better cognitive performance compared to an infant that nurses on infant milk formula (Farahwahida, 2011). A study from Holland showed that breast milk contains DHA and AA and are not found in artificial milk. Both are indispensable in the growth of the brain system. In addition, a study conducted at Cambridge and Flinders, Australia also has clearly shown that breastfed children have IQ intelligence that is capable of hitting a seven to ten IQ points than usual (Danial Zainal Abidin, 2007).

\section{Free from Bacteria}

Statements by a department on nutrition and drugs in the United States, as stated in an article entitled "Breast-Feeding Best for Babies", revealed that the content of breast milk is clean and free of bacteria. These include anti-bacterial substance known as macrophages where it is able to kill bacteria, fungi (fungi) and viruses. They found 80 percent of cells found in breast milk is made from it. Therefore, babies who drank milk gained a bit of resistance from various diseases such as inflammation of the lungs (pneumonia), inflammation of the airways (bronchitis), staphylococcus infections, influenza, ear infections and measles (Danial Zainal Abidin, 2007).

\section{Assisting Healing of Physiology of Mother}

Breastfeeding is also beneficial for the mother for her physiological healing after childbirth and during confinement. Among such healing is to stimulate uterine contractions after childbirth and to help restore the size of the mother's womb at the original level before pregnancy. Breastfeeding may also improve lactation amenorrhea term and distant their pregnancy (Farahwahida, 2011). Scientific studies also found that sucking by the baby during breastfeeding can help the recovery process of the new mother's womb. Meanwhile, according to Professor Arshad Hamid, women who breast-fed fully, at least in the last six months or more, rarely contracted breast cancer than women who never breast-feed (Che Wan Jasimah, 2003).

\section{Strengthen the Love between Mother and Baby}

In addition, breastfeeding also helps to establish closeness in love between a mother and her baby. This relationship is important for the formation of personality, infant growth and development, so that they will face more effective and vibrant future. Klaus (2007) states that the skin-to-skin touch between the mother and the baby is able to calm and soothe the soul. This feeling will stimulate the production of hormones known as oxitocin to produce more milk. Scientists also thought that frequent and prolonged contact between the baby and the mother contributes to the maturation of the baby's body functions such as apnea (breathing pauses) during long periods of sleep as compared to infants fed on milk formula. This is said to reduce the risk of Sudden Infant Death Syndrome (Farahwahida, 2011).

\section{Benefits to the Community and Country}

Studies conducted by the World Health Organization (WHO) indicate that breastfeeding is a highly potential strategy for human development that provides prospects to the future of society and the state of mental health. According to their report, mental illness is among five major diseases that cause disability and it is a disease expected to be the second highest in 2020. The same situation was also experienced by Malaysia as found in the report submitted by the National Health and Morbidity Survey III in 2006. An amount of 11.2 per cent of mental health occurred among adults, while 20.3 percent among children and teenagers. This factor is caused by insufficient breastfeeding in the first two years of life (Farahwahida, 2011). The 
study of Western Australian Pregnancy Cohort (Raine) found that breastfed babies over 6 months show a good level of mental health in childhood. They are less likely to be aggressive, extremely nasty, anti-social, depressed or anxious, uncontrolled and aloof (Oddy et al., 2010).

Table 2: Importance of Breast Milk Based on Quran and Science

\begin{tabular}{|r|r|r|l|}
\hline $\begin{array}{r}\text { Importance of Breast Milk According to } \\
\text { the Quran }\end{array}$ & \multicolumn{2}{|l|}{$\begin{array}{l}\text { Importance of Breast Milk According to } \\
\text { Science }\end{array}$} \\
\hline i. & Fulfilling the rights of the baby & i. & High colostrum level \\
\hline ii. & Early Childhood Education & ii. & Prolonged life \\
\hline iii. & Bonding of love and family relationship & iii. & $\begin{array}{l}\text { Increase in academic achievement and } \\
\text { IQ }\end{array}$ \\
\hline iv. & $\begin{array}{l}\text { Breasfeeding leads to establishing } \\
\text { mahram }\end{array}$ & iv. & Free from bacteria \\
\hline v. & Personality development & v. & Assist in curing mother's physiology \\
\hline \multirow{2}{*}{} & & vi. & $\begin{array}{l}\text { Enhance love bonding between mother } \\
\text { and child }\end{array}$ \\
\cline { 3 - 4 } & vii. & Benefit to the society and the nation \\
\hline
\end{tabular}

\section{Breastfeeding in Child's Law}

\section{BREASTFEEDING ISSUES RELATED TO SYARIAH}

Through the words of Allah swt in Surah al-Baqarah: Ayat 233, it explains that, the Quran strongly encourages parents to try to enhance responsibility through breastfeeding. Although there is no evidence from the Quran that states clearly the link of breast-feeding law, jurists have established that breastfeeding is the right of a baby to be carried out by parents. Therefore, parents should take matters relating to breastfeeding of infants seriously. This is because breast milk is the best milk and recognized by all physicians.

According to the Shafi'i school of scholars, the responsibility of managing breastfeeding is that of the father's or the husband's. It is one of the maintenance that must be carried out to fulfill the needs of their children. According to some scholars of Maliki, the responsibility of the nursing mothers takes place when the mother is healthy and there are no obstacles and problems that cause the baby not to suckle. If a mother is sick and she cannot breastfeed, then at that point the obligation is moved to her husband so that he can try to find someone for the mother's milk or hire someone else to breastfeed her child. According to the scholars of the Hanafi school, obligations or responsibilities of a mother who is not able to breastfeed is to seek others to breastfeed her child, and that when the child is not able to take in the milk or other milk or no milk of its mother and also the difficulties of others. Rejection of a mother from breastfeeding her child is not considered as treason (nasyizah), because breastfeeding is not a task that is considered mandatory. However, in the event of an emergency to the baby that no one can breastfeed unless the mother, then the mother should breastfeed their babies for the sake of saving lives (Moses, 2009).

\section{Lineage through Breastfeeding}

Scholars have agreed that marriage is illegal if due is caused by breastfeeding, if breastfeeding is reached five times of full milking. Imam Shafi'i and Imam Hanbali sought to the Hadith narrated by Aishah r.a. which means "The Quran was revealed about breastfeeding that a 
suckling child is mahram with ten times of full milking. Then it has been replaced to five times of full milking only. Upon Prophet's (pbuh) demise, the decision on five times of full milking remains"(al-Zuhaili, 2007). Scholars of the Hanafi and Maliki sects also differ in terms of the period that deems as mahram through breastfeeding. They have agreed to stick to the law that whether there is more milk or less milk based on the words of Allah swt which means "Forbidden to you are the following: your mothers, and your children, siblings, your father's siblings, your mother's siblings, your nephews and your nieces, and your mothers that have suckled you, and your milk siblings".

\section{Establishment of the Milk Bank}

According to al-Zuhayli (2007), creating institutions such as a milk bank is not allowed in Islam because it contains elements of damage (mafsadah) in terms of mixed ancestry which is not shari'ah-compliant and there are uncertainties of wet nurse, although this idea is said to have the values of humanity against babies who suffer from certain diseases. This idea has also issued a doubt on the necessity of law and its ban because one can become mahram through breastfeeding (radha') and as a mahram its descent (lineage) is created. Al - Zuhayli supports the resolution 6 (2/6) Council of the International Islamic Fiqh (Islamic Fiqh Academy, 2000) that was against this idea and the Council has already provided an alternative solution on this issue. He thought that drinking milk from a milk bank is not allowed because it leads to mixed lineage which is not Shariah-compliant. After the research was made with regard to the fiqh issue on milk bank, the International Islamic Fiqh Council has found that:

i. Milk bank initiative is a test and experiment conducted by the Western nations. However, this institution is getting less attention because the elements raised negative elements based on studies and scientific reviews.

ii. All Muslims have come to an absolute agreement that impression and effect of breastfeeding (radha') is the same as affinity and blood (nasab). Islam came with the aim to safeguard the interests of offspring (nasab) and the establishment of milk banks may lead to mixing wayward offspring which may not be shari'ah-compliant and may spread doubts.

iii. Babies who are underweight or suffering from certain diseases which make the body as an antidote, should still be treated through regular feedings as the same process by the birth mother or the wet mother. From this perspective, the milk bank is viewed as irrelevant.

For these reasons, the National Fatwa Council for Islamic Religious Affairs Malaysia has decided that the establishment of milk banks is not required. This is so to prevent Muslims from being lured to doubt and that which is unlawful. As this is not a matter of emergency, the milk bank is unnecessary as there are other alternatives such as wet nurse and milk-making hormone booster.

\section{CONCLUSION}

Every baby born on this earth needs to be guaranteed perfect feeding for their health. This is evident through the encouragement given by the Quran and Hadith, which bestows responsibility to the parents to ensure that their children get the perfect feed at the beginning of their birth until adulthood. In fact, scientific studies also have similarities that can be verified by the Quran and the teachings, that is the recommendations presented to humans with regard to breastfeeding. The effect of breastfeeding propagated in Islam, upheld by the principles and conditions, has clearly shown that breastfeeding rights and convictions with maternal lineage are among the key elements that need to be clarified. In addition, there are advantages and 
benefits of the health aspects of breastfeeding for both baby and the mother. There are also important issues of maternal milk because it affects the conviction of consanguinity that should be considered in order to avoid any problems with regard to mahram and marriage. Undeniably, breastfeeding not only has a positive effect in terms of physiology and immunology, but it also has a positive impact psychologically. In addition, apart from strengthening the bond of affection between mother and child, it also maintains the mother's mental health. By all the evidences presented either from the Quran or by the scientists, there are no contradictions or differences. With this, it clearly shows us that breastfeeding is guaranteed and is not only beneficial to the mother and baby, but also to the society and the country in general. Therefore, various parties must play a role in alerting the public, especially working women not to underestimate the significance of breastfeeding.

\section{References}

Abdul Karim Ali (2006). Produk Hibah dan Kesannya Kepada Pencapaian Maqasid Dalam Sistem Kekeluargaan Islam di Malaysia. dalam International Conference On Islamic Jurisprudence And The Challenges Of The 21st Century: Maqasid al-Shariah and its Realization in Contemporary Societies. 8-10 August 2006. Kuala Lumpur: International Islamic University Malaysia

al-Syeikh, Faruq Abd. Najm al-Abdali (2007). Sains dari Perspektif Kitab Samawi terj. Nazrah Ilmiyah Lil Kutub asSamawiyyah. Kuala Lumpur: Institut Terjemahan Negara Malaysia

Al-Zuhaili, Wahbah (2007). Fatwa-fatwa Semasa terj. Fatawa Mua`sirah. Kuala Lumpur. iBook Publications.

Ayu Aima Yusuf. (2002). Penyusuan Susu Ibu Menurut Perspektif Islam. Kuala Lumpur: Utusan Publications \& Distributors Sdn Bhd

Che Wan Jasimah Wan Mohamed Radzi. (2003). Konsep Kesihatan Melalui Pemakanan Pendekatan Islam dan Sains. Kuala Lumpur: Utusan Publications and Distributors Sdn. Bhd.

Danial Zainal Abidin. (2007). Quran Saintifik : Meneroka Kecemerlangan Quran Daripada Teropong Sains. Selangor: PTS Millennia Sdn. Bhd.

Else-Quest, N.M., Hyde, J.S., \& Clark, R. (2003). Breastfeeding, Bonding, and The Mother-Infant Relationship. Merrill-Palmer Quaterly, 49 (4), 495-517.

Farahwahida, Mohd Yusof., Zilal, Saari., Marwah, Saari (2011). Al-Quran dan Sains Berbicara Mengenai Susu Ibu daripada

http://mardhotillah-bp.blogspot.com/2011/09/susu-ibu-menurut-sains.html

Islamic Fiqh Academy (2000). Resolutions and Recommendations of the Council of the Islamic Fiqh Academy 1985-2000. Jeddah: Islamic Development Bank

Jenny Bond. T. \& Filler, L. J. Jr. (1981). Infant \& Child Feeding. New York: Academic Press Inc.

Kramer, M.S., et al. (2008). Breastfeeding and Child Cognitive Development: New Evidence from A Large Randomized Trial. Archive General Psychiatry, 65 (5), 578-584.

Khulqi Rashid(2007).Al-QuranbukanDabVinci's Code. Jakarta:Mizan Media Utama

Marshall Klaus (2008). Mother and Infant: Early Emotional Tie in Pediatrics 1998;102;1244-

Oddy WH, Kendall GE, Li J, Jacoby P, Robinson M, de Klerk NH, Silburn SR, Zubrick SR, Landau LI, Stanley FJ (2010). The long-term effects of breastfeeding on child and adolescent mental health: a pregnancy cohort study followed for 14 years. In J Pediatr. 2010 Apr;156(4):568-74.

Suriati Ghazali. (1998). Menyusukan Bayi : Mengatasi Halangan Mental dan Sosial. Kuala Lumpur: Utusan Publications and Distributors Sdn. Bhd.

Tafsir pimpinan Ar-Rahman kepada pengertian al-Qur'an (1995) Kuala Lumpur: Jabatan Kemajuan Islam Malaysia 
Zalma Bt. Abdul Razak, Zuhaida Bt. Harun, Nazli Suhardi B. Ibrahim (2009). Kebaikan Susu Ibu di http://www.myhealth.gov.my/index.php/pemakanan/penyusuan-susu-ibu/kebaikan-susu-ibu (di akses 8 Febuari 2015)

Sistem Kekeluargaan Islam, Musa Fathullah Harun (2009), Kuala Lumpur: Syarikat Merza 